\title{
Fleeing Domestic Violence from a "Safe" Country?: Refugee Determination for Mexican Asylum-Seekers in Canada
}

\author{
RUPALEEM BHUYAN, ADRIANA VARGAS, AND MARGARITA PÍNTÍN-PEREZ
}

\begin{abstract}
This article presents a mixed-methods study of domesticviolence-related claims for Mexican asylum-seekers in Canada. Although refugee claims that indicate domestic violence are slightly more likely to be approved, the majority of Mexicans seeking protection from domestic violence are denied because they are unable to demonstrate the lack of state protection. Our findings illustrate that Immigration and Refugee Board members' assessment of a claimant's credibility, internal flight alternatives, and the availability of state protection pivot on their perception of Mexico as a "democratic" or "safe" nation. We discuss how cursory attention to the social context of gendered violence in Mexico leaves Mexicans with few legal options for humanitarian migration.
\end{abstract}

\section{Résumé}

Cet article présente une étude à méthodologie mixte des demandes d'asile au Canada reliées à la violence conjugale de la part des Mexicains. Bien que les demandes faisant mention de violence conjugale ont plus de chances d'être accordées, la plupart des Mexicains réclamant une protection de la violence conjugale sont jugés non-admissibles en raison de leur incapacité de démontrer un manque de protection de la part de l'état. Nos recherches démontrent que l'évaluation de la part des membres de la Commission de l'immigration et du statut de réfugié concernant la crédibilité des demandeurs, la possibilité de refuge intérieur et la disponibilité de protection de la part de l'état dépend de leur perception du Mexique en tant que pays «démocratique» ou «sûr». Nous abordons une discussion sur l'attention insuffisante portée au contexte social de la violence sexospécifique au Mexique qui laisse peu d'options légales aux Mexicains en ce qui concerne la migration pour raisons humanitaires.

\section{Introduction}

7 his article examines how domestic violence configures into refugee determination for Mexican asylumseekers in Canada prior to Mexico's official designation as a "safe country of origin." Domestic violence falls under the Immigration and Refugee Board of Canada's (IRB) guidelines for "Women refugee claimants fearing gender-related persecution" (herein referred to as the "Gender Guidelines"). Since the Gender Guidelines were first introduced in 1993, there has been a positive trend towards recognizing gender-related persecution in Canada's refugee process. ${ }^{1}$ However, legal scholars note limitations within the United Nations framework for determining refugee status for people fleeing gender-related persecution. ${ }^{2}$

Foremost, Arbel and colleagues ${ }^{3}$ caution that many women are never seen in the Canadian refugee determination process, because they cannot leave their home country or do not have the means to apply. Increased border controls across North America construct forced migrants as "illegal," further exposing migrant women to structural and 
interpersonal violence. ${ }^{4}$ This is particularly true for Central Americans, who are subject to detention and removal by both the Mexican and U.S. governments. 5

In this article, we present a case study of refugee claims submitted by Mexican nationals that indicate domestic violence as one reason for seeking protection in Canada. To set the groundwork for our study, we review trends in humanitarian migration from Mexico to Canada. We then discuss the concept of "safe" country in Canadian refugee determination. To contextualize the IRB's assessment of Mexican refugee claims, we reviewed academic and grey literature on violence against women in Mexico, where domestic violence, rape, and femicide are systematically ignored or dismissed. ${ }^{6}$ After discussing our research methods, we present an empirical analysis of IRB's assessment rates for Mexican refugee claimants, and key themes that emerged from our analysis of negative decisions written by the IRB members. 7 Our findings illustrate that the availability of state protection from domestic violence pivots on the construction of Mexico as a "safe" nation, despite evidence of escalating violent crimes and impunity across Mexico.

\section{Legal Context of Violence against Women in Mexico}

Estados Unidos Mexicanos (United Mexican States) is a democratic republic made up of thirty-one states and a federal district, Mexico City, the nation's capital and the largest city in the western hemisphere with 21.2 million residents. Escalating levels of violence across Mexico have had a direct impact on women's safety. ${ }^{8}$ The majority of adult women are victims of some kind of violence from the hands of their spouse, partner, or former partner. ${ }^{9}$ Mexico is ranked sixteenth in the world for female homicides. ${ }^{10}$ These findings, alongside international pressure, encouraged Mexican elected officials to develop legislation in line with the Convention on the Elimination of All Forms of Discrimination against Women (CEDAW). In 2007, the General Law on Women's Access to a Life Free of Violence (herein referred to as the General Law) became Mexico's primary legal framework for addressing violence against women.

The General Law directs federal, state, and municipal governments to respond to, prevent, punish, and eradicate violence against women. ${ }^{11}$ Implementation of the General Law thus varies widely relative to regional and local political interests, and coordination among states and municipal governments. ${ }^{12}$

\section{Context of Humanitarian Migration from Mexico to Canada}

Although humanitarian migration from Mexico to Canada is a relatively new phenomenon, in the past two decades
Canada recognized the largest number of Mexican asylumseekers in the world. According to the UNHCR, ${ }^{13}$ 172,926 Mexicans applied for asylum between 2000 and 2014. The majority of Mexican asylum-seekers (73\%) submit their claims in the United States. Canada, however, approves the largest share of Mexican refugee claims. Between 2000 and 2014, Canada recognized 7,777 Mexican refugees (70\% of the worldwide total) while the United States recognized only 3,287 (29.6\%). During this same period, only 46 Mexicans were recognized as refugees by other countries (see tables 1 and 2).

There are notable differences between asylum claim processes in the United States and Canada. People who submit a claim within Canada are referred to as "refugee claimants" and have access to basic health care and social assistance, and are authorized to work while they await a decision. In 2014, Canada processed 13,500 new claims and approved 9,869 refugee claimants from previous years at an approval rate of $49 \% .{ }^{14}$ Canada also offers permanent residence on humanitarian and compassionate grounds to a small number of people who can demonstrate that removal from Canada would represent a violation of their rights.

In the United States, refugees may submit an asylum claim within one year of their last entry either proactively (i.e., before being detained by immigration authorities) or defensively (i.e., submitted after being placed in removal proceedings in Immigration Court). The United States has high evidentiary requirements but little support for asylumseekers to navigate the complex legal system (e.g., asylumseekers are not eligible to work until their claim has been approved). U.S. rates of approving Mexican asylum claims dropped from $23 \%$ to $9 \%$ between 2008 and $2013 .{ }^{15}$ The United States also offers Temporary Protected Status (TPS) to some refugees from Central America (e.g., Honduras, Nicaragua), which allows them to work and reside legally in the United States for a short period. Mexican nationals are not eligible for TPS at this time.

In 2009, Canada introduced a visa requirement for Mexico to block the entry of asylum-seekers whom the Canadian minister of citizenship and immigration denounced as "bogus refugees." ${ }^{\text {"6 }}$ Mexico was later added to a list of Designated Countries of Origin in 2012, as another policy instrument to deter humanitarian migration from "safe countries." The Conservative Canadian government's revision of refugee law in 2012 restricted access to public benefits, institutionalized forced detention for refugees whose entry into Canada was deemed "irregular" (i.e., they were trafficked), and reduced access to health care (although health care was restored in April 2016). ${ }^{17}$ The efficiency principles of this reform were aimed specifically at refugee claimants who originate in a "safe country of origin" who now have a 
Table 1. Recognized Mexican refugee claims, 2000-2014

\begin{tabular}{lrrr}
\hline Year & Canada & USA & Other \\
\hline 2000 & 322 & 84 & 2 \\
2001 & 237 & 75 & 0 \\
2002 & 290 & 68 & 0 \\
2003 & 597 & 94 & 0 \\
2004 & 665 & 104 & 0 \\
2005 & 697 & 89 & 0 \\
2006 & 931 & 109 & 0 \\
2007 & 378 & 113 & 0 \\
2008 & 606 & 161 & 0 \\
2009 & 516 & 212 & 4 \\
2010 & 653 & 164 & 6 \\
2011 & 1,042 & 337 & 5 \\
2012 & 568 & 560 & 10 \\
2013 & 182 & 430 & 13 \\
2014 & 93 & 687 & 6 \\
\hline Totals & 7,777 & 3,487 & 46 \\
\hline Percentage & $70 \%$ & $29.6 \%$ & $0.4 \%$ \\
\hline Sol & $70 \%$ &
\end{tabular}

Source: UNHCR Statistical Online Population Database.

Note: Countries in the "Other" category included Australia, Italy, Switzerland, United Kingdom, Panama, Belgium, Cayman Islands, Luxemburg, Trinidad and Tobago.

shorter period to submit their refugee application and have fewer rights for appeal. Refugee claimants fleeing domestic violence, who often need more time to collect supporting documents, are particularly disadvantaged by restrictions on their procedural rights.

\section{Designating "Safe" Countries in Canadian Refugee Law}

A "safe third country" provision was first introduced into Canadian law in 1987, when Bill C-55 was tabled during an emergency session of Parliament to address the arrival of two "boatloads" 18 of South Asian refugees on the Atlantic coast. Bill C-55 created the Immigration and Refugee Board (IRB) as a measure to streamline refugee determination. This bill also introduced a "safe third country" provision to allow Canada to return claimants who had sojourned in another country. The practice of deflecting responsibility for asylum-seekers had been established in Western Europe through the Dublin Regulation, signed in 1990 by twelve countries in Western Europe. Bill C-55 went into effect in 1989. The "safe third country" measure, however, was not
Table 2. Mexican asylum/refugee claims filed 2000-2014

\begin{tabular}{lrrr}
\hline Year & Canada & USA & Other \\
\hline 2000 & 1,310 & 9,145 & 11 \\
2001 & 1,669 & 21,484 & 3 \\
2002 & 2,397 & 23,748 & 8 \\
2003 & 2,576 & 11,660 & 7 \\
2004 & 2,918 & 1,763 & 16 \\
2005 & 3,541 & 1,581 & 10 \\
2006 & 4,948 & 1,673 & 20 \\
2007 & 7,028 & 2,551 & 33 \\
2008 & 8,069 & 2,713 & 24 \\
2009 & 9,296 & 2,295 & 74 \\
2010 & 1,299 & 3,879 & 106 \\
2011 & 763 & 8,304 & 95 \\
2012 & 382 & 11,067 & 123 \\
2013 & 110 & 10,077 & 105 \\
2014 & 65 & 13,987 & 64 \\
\hline Total & 46,355 & 125,927 & 699 \\
\hline Percentage & $26.8 \%$ & $72.8 \%$ & $0.04 \%$ \\
\hline
\end{tabular}

Source: UNHCR Statistical Online Population Database.

Note: There are 38 countries in the "Other" category in Western Europe, Central America and the Caribbean, and Australia. No country in the "Other" category received more than 20 applications in a given year. Most countries received from 1-2 applications in a given year.

enforced because there were complicated logistics of returning refugee claimants to a previous country of sojourn. ${ }^{19}$

The concept of a "safe country" reappeared in the CanadaU.S. Safe Third Country Agreement (sTCA) after the events of 11 September 2001. ${ }^{20}$ The sTCA allows Canada to turn away asylum-seekers at the U.S.-Canadian border (i.e., land border crossings, airports, and train stations), under the presumption that they can submit a refugee claim in the United States, unless they qualify for an exception to the Agreement (e.g., people who have family in Canada, unaccompanied minors, people who hold a valid work or study permit in Canada, people who hold a valid travel document or may be issued a travel document upon entry to Canada). After the introduction of the STCA, the number of refugee claims filed at the border fell $50 \%$ and remain low, with 3,790 filed in $2012 .{ }^{21}$

The list of DCO countries introduced into Canadian law in 2012 draws upon a different notion of a "safe" country by presuming that legal institutions where the asylum-seeker originated have the capacity to ensure justice. Asylum-seekers from "safe countries of origin" bear the onus of proving that institutions within their home country failed to protect them. 
The combination of visa restrictions, the STCA, and designating Mexico as a "safe country of origin" contribute to a marked decrease in the number of in-land refugee applications that were submitted by Mexicans in Canada since 2012. ${ }^{22}$ While new refugee claims peaked at 9,296 in 2009 (for principal claimants and their dependants), this number plummeted to 1,299 in 2010 following the new visa requirement; only 65 new claims were filed in $2014^{23}$ (see table 2). The number of new asylum claims filed during this same year in the United States grew by 4,000 and continued to rise to 13,987 new refugee claims filed in the United States in 2014.

\section{Gender and Domestic Violence in Canadian Refugee Policy}

When the Gender Guidelines were first introduced, feminist legal scholars commended them as a positive direction for women's rights, while calling attention to the limits of refugee determination. Mawani ${ }^{24}$ forecasted many of the hurdles that women seeking protection due to genderrelated persecution would face, including (1) that persecution against women often takes place in intimate relations where the state plays an indirect role; (2) that evidentiary requirements presume women have access to male-dominated legal systems; and (3) the assumption that women have the same mobility as men, when relocating alone or with their children.

Refugee determination reifies Canada as a democratic nation that has the power to determine which nations are incapable of ensuring protection from gender-related persecution. Macklin ${ }^{25}$ has argued that Western feminists have a penchant to rally against the misogyny and sexism in the Third World while lauding the success of the women's movement in the West. In viewing itself as a "refugee receiving state," assessment of gender persecution by the Canadian IRB pivots around what Macklin calls "cultural chauvinism ... to distinguish between those states which are 'unwilling or unable' to protect women from domestic violence (nondemocracies, current refugee producers), and those states whose justice systems are simply 'imperfect' and cannot be held accountable for an inability to protect each individual woman from each individual criminal assailant (democracies and general respecters of human rights)." ${ }^{26}$ Attention to violence against women in refugee determination thus has the potential to minimize the prevalence of violence in North American society towards maintaining the binary of "refugee-producing" versus "refugee-receiving" states.

Razack $^{27}$ similarly argues that Canadian refugee hearings perpetuate racist constructions of culture while dismissing the complicity of the Canadian state in failing to protect women from gender-based violence. ${ }^{28}$ The refugee hearing requires claimants to construct gender persecution as a cultural problem. Claimants are more successful when they present cases of violence that are viewed as "non-Western, inferior, and unusually barbaric towards women." 29 When the form of persecution is constructed as a type of "cultural practice" (i.e., female genital mutilation), the state's complicity in failing to protect women is more readily assumed.

In Arbel's ${ }^{30}$ review of IRB decisions on gender-related persecution, "cultural practices" that warrant refugee protection (e.g., genital cutting or forced sterilization) were framed as a "violation of rights regarding persecutory practices." In contrast, women who reported domestic violence had to demonstrate that the state failed to protect them as the result of its "persecutory culture." Arbel further noted that adjudicators look favourably on countries that make "good-faith efforts to take the problem of violence against women seriously by enacting legislation, training specialized police units, providing legal-aid services, or establishing shelters or other forms of recourse or support." ${ }^{11}$ The presence of legislation that criminalizes violence against women signals to adjudicators that this is a democratic nation and this nation is trying to offer protection. The combined effect increases the burden on the claimants who experience forms of violence that do not fit the cultural script of "barbaric," to prove that their state's legal system failed to protect them.

The effectiveness of the Gender Guidelines is difficult to measure because refugee hearings are closed to the public. Positive decisions are not routinely written, and only a fraction of negative decisions are publicly available. This contributes to the "unknowability" of how gender influences adjudicators' decision making. 32

Sean Rehaag ${ }^{33}$ has also documented alarming variance in rates of approval by individual IRB members. In 2006, approval rates ranged from $100 \%$ for 1 adjudicator to as low as $6.7 \%$ for another, for comparable cases. Rehaag also reports that rates of approval vary slightly with the gender identity of the adjudicator; between 2004 and 2008, male adjudicators approved $51.5 \%$ of claims in their caseload as opposed to $48.6 \%$ that were approved by female identified adjudicators. Adjudicators who had prior experience with women's rights-all of whom were women-were more likely to approve claims for refugees who sought protection from gender-related persecution. 34

Building on previous scholarly attention to Canada's Gender Guidelines, our research examines where domestic violence appears in refugee determinations for claimants from a specific country and how IRB members characterize the country of origin's capacity to protect women from gender-related persecution, in their written decisions. 


\section{Methodology}

Our research design included qualitative and quantitative research methods to explore how public texts construct domestic violence for Mexican women seeking refuge in Canada. We draw upon feminist and critical theories of "language as a social practice" 35 to analyze how ideologies are enacted, sustained, and challenged in different contexts. ${ }^{36}$ We theorize discourse as a "site of struggle," a system of representation for social action, a source and expression of power, and site where subjectivities are constructed, contested and resisted. ${ }^{37}$ In particular, we examine how public documents (i.e. IRB reports, IRB written decisions) construct domestic violence for refugee claimants, what types of knowledge are referenced in official documents, and what linguistic markers (e.g. speech acts, rhetoric) do IRB adjudicators use in their written decisions.

Our sources of data include: (1) IRB statistics on principal applicants of refugee claims submitted by Mexican nationals between 2007 and 2012; (2) IRB data for Mexican refugee claims that included domestic violence when the claim was submitted; and (3) written decisions by IRB adjudicators for claims related to domestic violence that are published online by the Canadian Legal Information Institute (CanLII)..$^{38}$ To better understand the IRB's assessment of Mexico as a "safe" country, we reviewed reports on "country conditions" for Mexico that are maintained by the IRB.

\section{IR B Data for Mexican Refugee Claimants, 2007-2012}

We examined refugee claim data from the IRB that were retrieved by Sean Rehaag through an Access to Information Request and made available to the public through the Canadian Council for Refugees website. 39 These data include the outcomes for decisions on principal applicants only, thus do not include accompanying partners or dependent children.

\section{IRB Data for Mexicans Who Sought Protection from Domestic Violence}

Through a formal Access to Information Request, we reviewed IRB claim data for Mexicans who sought protection from domestic violence between 2008 and 2012. The IRB provided the number and gender of claims that reported domestic violence as the basis for their claim at the time of initially filing the claim (i.e., through the Personal Information form or Basis of Claim form). The IRB stipulated that they maintain these records for case management only. IRB staff do not update the "claim type" categories during the claim review, nor does the IRB maintain records for claims where domestic violence was a relevant factor in the final decision.
IRB Determinations for Mexicans Seeking Protection from Domestic Violence

We conducted a discourse analysis of 76 IRB written decisions for claimants from Mexico ( 75 female; 1 male), between 2007 and 2012 that are available through the CanLiI and LexisNexis/Quicklaw databases (see table 3). The CanLII database publishes a portion of decisions that are released by the Federal Court of Canada, the majority of which are negative decisions that have been submitted for appeal to the Federal Court. We drew a sample from 2007 to 2012 using the search terms female and Mexico, followed by a range of terms including domestic violence, violence against women, and sexual assault. We also ran a separate search using only the terms Mexico and partner abuse. For this analysis, we did not track the outcome of the judicial review, but rather focused on the content of the initial negative decision.

\section{IRB "National Documentation Package" for Mexico}

We conducted a content analysis of the National Documentation Package for Mexico, which IRB board members regularly cite in their written decisions. We focussed on documents that the IRB maintained between 2005 and 2012, which address domestic violence and other forms of violence against women in Mexico.

\section{Grey and Academic Literature on Violence against Women in Mexico}

We conducted a review of Spanish- and English-language academic and grey literature on country conditions and violence against women in Mexico. This included analysis of over 30 documents retrieved from governmental bodies including the Mexican National Institute of Women, the National Commission to Prevent and Eradicate Violence against Women, the National Institute of Statistics and Geography, and the National Commission of Human Rights. The majority of the reports we reviewed evaluate implementation of the General Law in specific areas of Mexico, the incidence and prevalence of violence against women, and the services available to victims. We also reviewed reports published by non-governmental organizations such as Human Rights Watch and Amnesty International that provide detailed information regarding the situation of gender-based violence in Mexico. Academic scholarship by Castro and Riquer, Frias, and Olivera ${ }^{40}$ provided structural analysis of impunity for violent crimes against women in Mexican society. 
Table 3. Summary of IRB written decisions for Mexican claimants, 2007-2012

\begin{tabular}{|c|c|c|c|c|c|c|c|c|}
\hline & 2007 & 2008 & 2009 & 2010 & 2011 & 2012 & Total & $\%$ \\
\hline Number of claims reviewed & 18 & 19 & 12 & 13 & 6 & 8 & 76 & \\
\hline \multicolumn{9}{|l|}{ Reasons for denial } \\
\hline Credibility & 6 & 5 & 4 & 5 & 5 & 4 & 29 & 38 \\
\hline Internal flight alternative & 9 & 14 & 7 & 5 & 5 & 2 & 42 & 55 \\
\hline State protection & 8 & 11 & 8 & 10 & 4 & 7 & 48 & 63 \\
\hline Combination of 2 or more & 5 & 9 & 6 & 5 & 6 & 4 & 35 & 46 \\
\hline \multicolumn{9}{|l|}{ Type of violence } \\
\hline Physical abuse & 14 & 17 & 11 & 10 & 6 & 5 & 63 & 83 \\
\hline Verbally threatened & 8 & 12 & 5 & 8 & 4 & 3 & 40 & 53 \\
\hline Emotional abuse & 2 & 1 & 3 & 2 & 2 & 2 & 12 & 16 \\
\hline Kidnapped or attempt to kidnap & 1 & 1 & 0 & 0 & 0 & 0 & 2 & 3 \\
\hline Sexual abuse & 4 & 6 & 4 & 5 & 2 & 3 & 24 & 24 \\
\hline Abuse (no further description) & 3 & 1 & 0 & 2 & 0 & 1 & 7 & 9 \\
\hline \multicolumn{9}{|l|}{ Reports of seeking help } \\
\hline Did seek police/state protection & 11 & 14 & 8 & 9 & 4 & 7 & 53 & 70 \\
\hline Did seek to relocate & 8 & 8 & 5 & 7 & 2 & 4 & 34 & 45 \\
\hline
\end{tabular}

Source: We retrieved this sample of IRB written decisions through the CANLII and LexisNexis/Quicklaw databases.

In our analysis of written decisions, we consider the ramifications of how IRB members characterize claimants' accounts of domestic violence. We also explore how representations of Mexico are mobilized to support IRB members' decisions to dismiss or deny protection.

\section{Findings}

Assessing the National Documentation Package for Mexico

The IRB's National Documentation Package for Mexico includes reports on narco-related violence, human rights violations, and general impunity in the criminal justice system. Several documents briefly refer to the General Law and identify women's shelters and support systems that have been established to support women seeking safety from genderrelated violence. The weakness in the General Law is noted in limited resources and safety for women's shelters. One IRB report documented that shelters in Mexico, unlike Canada, "do not receive police protection, and attacks against staff and facilities have been reported." 41 The National Institute for Women in Mexico also identified a need for additional shelters, particularly in Mexico City where there are only 4 shelters for a population of over 21 million.

The documentation package, however, does not fully address the political conditions that influence implementation of the General Law. We noted minimal attention to government and independent reports that address the lack of coordination among government bodies as well as the high levels of insecurity in many regions of Mexico, both of which significantly undermine the protection these laws are purported to offer. For example, the IRB documents only refer to the implementation of the General Law in the state of Sonora and state protection available to victims of domestic violence in Mexico City, Jalisco, and Veracruz.

The limited scope of the National Documentation Packages is evident in cases of female homicide (or femicide), which first drew international attention in 1993 following the expansion of maquiladoras (factories) along the Mexico-U.S. border. The United Nations and grassroots activists have documented numerous cases where young women who disappear and are sexually tortured and murdered, their bodies often found in public spaces across Mexico. ${ }^{42}$ While 30 out of the 32 Mexican states have criminalized femicide, the majority of cases go without formal investigation at the federal and local levels. Impunity for violent crimes extends to non-gender-related homicides, with less than $10 \%$ of homicides leading to convictions, including the widely reported mass killing of 43 male students from the Ayotiznapa Rural Teachers' College in Guerrero. ${ }^{43}$

\section{Summary of Refugee Claims from Mexico}

According to IRB administrative data, Canada issued 16,028 decisions for Mexican asylum-seekers between 2007 and 2012. Decisions peaked at 3,389 in 2011, then dropped to 1,660 in 2012 . On average $10 \%$ of the decisions were positive; $55 \%$ were negative; $29 \%$ were reported as withdrawn or 
Table 4. IRB decisions: Principal applicants from Mexico, 2007-2012

\begin{tabular}{|c|c|c|c|c|c|c|c|c|c|}
\hline \multirow[t]{2}{*}{ Year } & \multirow[t]{2}{*}{ Total } & \multicolumn{2}{|c|}{ Gender } & \multicolumn{2}{|c|}{ Positive } & \multicolumn{2}{|c|}{ Negative } & \multicolumn{2}{|c|}{$\begin{array}{l}\text { Withdrawn or } \\
\text { abandoned }\end{array}$} \\
\hline & & Male & Female & Male & Female & Male & Female & Male & Female \\
\hline \multirow[t]{2}{*}{2007} & 2,150 & 1,488 & 662 & 88 & 96 & 793 & 322 & 604 & 243 \\
\hline & & $69 \%$ & $31 \%$ & $5.9 \%$ & $14.5 \%$ & $53 \%$ & $49 \%$ & $41 \%$ & $37 \%$ \\
\hline \multirow[t]{2}{*}{2008} & 1,958 & 1,323 & 633 & 125 & 131 & 1,198 & 502 & $\mathrm{~N} / \mathrm{A}$ & N/A \\
\hline & & $68 \%$ & $32 \%$ & $9.4 \%$ & $21 \%$ & $91 \%$ & $79 \%$ & & \\
\hline \multirow[t]{2}{*}{2009} & 3,497 & 2,429 & 1,066 & 109 & 108 & 1,178 & 515 & 1132 & 438 \\
\hline & & $69 \%$ & $30 \%$ & $4.5 \%$ & $10 \%$ & $48 \%$ & $48 \%$ & $47 \%$ & $41 \%$ \\
\hline \multirow[t]{2}{*}{2010} & 3,374 & 2,342 & 1,032 & 145 & 141 & 1,300 & 502 & 894 & 387 \\
\hline & & $69 \%$ & $31 \%$ & $6.2 \%$ & $14 \%$ & $56 \%$ & $49 \%$ & $38 \%$ & $38 \%$ \\
\hline \multirow[t]{2}{*}{2011} & 3,389 & 2,384 & 1,005 & 224 & 209 & 1,663 & 622 & 495 & 172 \\
\hline & & $70 \%$ & $30 \%$ & $9.4 \%$ & $21 \%$ & $70 \%$ & $62 \%$ & $21 \%$ & $17 \%$ \\
\hline \multirow[t]{2}{*}{2012} & 1660 & 1,161 & 499 & 129 & 134 & 862 & 295 & 167 & 70 \\
\hline & & $70 \%$ & $30 \%$ & $11 \%$ & $27 \%$ & $74 \%$ & $59 \%$ & $14 \%$ & $14 \%$ \\
\hline Total & 16,028 & 11,127 & 4,897 & 820 & 819 & 6,994 & 2,758 & 3,292 & 1,310 \\
\hline$\%$ & - & $66 \%$ & $29 \%$ & $7.4 \%$ & $16.7 \%$ & $63 \%$ & $56 \%$ & $30 \%$ & $27 \%$ \\
\hline
\end{tabular}

Source: IRB claim data published by Sean Rehaag (2008, 2013).

Note: "Gender" includes total number of male and female principal applicants per year along with the percentage of males and females relative to the total. The values reported for decisions that were "positive," "negative," or "withdrawn/abandoned" include the total male and female principal applicants in each category, along with percentage for each gender (i.e., in $2007,4 \%$ of male applicants and $4.5 \%$ of female applicants received a positive decision).

abandoned; and $1 \%$ were closed for administrative reasons. On average $31 \%$ of Mexican principal applicants were female. Female principal applicants have a slightly higher approval rate of $16 \%$. In 2009, the IRB reported that 257 claims were gender-related; this information was not available for other years in our date range (see table 4 ).

Between 2008 and 2012, the IRB received 595 claims from Mexican nationals that included domestic violence as a basis of the initial claim; the majority (95\%) were filed by women (see table 5). Among female claimants from Mexico, $14 \%$ indicated domestic violence in their original claim. On average, $26 \%$ of domestic-violence-related claims received a positive decision, which is a higher rate of approval than Mexican refugee claims overall, but significantly lower than the $48.7 \%$ approval rate that Arbel 44 reported in her review of all IRB decisions for principal applicants who reported domestic violence, from 2008 to 2012.

There are limitations, however, to the IRB administrative data. The IRB does not record which applicants are transgender or if the claimant feared domestic violence from a samesex spouse or partner. Because the IRB does not track forms of persecution that arise after the initial application, it is possible that persecution other than "domestic violence" contributed to a claim's outcome or that some claimants disclosed persecution related to domestic violence after filing the initial claim. In addition, because a limited number of negative decisions are publicly available, it is difficult to assess how often "domestic violence" contributes to a refugee claim's outcome. Finally, our research did not address the disparity in individual IRB members' rates of approving applications.

\section{Analysis of Domestic Violence in Negative IRB Decisions}

\section{Summary of the Negative Decisions}

In our analysis of 76 written decisions, 8 did not mention gender or the Gender Guidelines anywhere in the decision. Of the 68 decisions that did reference the Gender Guidelines, more than two-thirds used the following statement and made no other reference to the Gender Guidelines: "In arriving at its decision, the panel considered all of the evidence in the context of the Chairperson's Gender Guidelines and the panel accepts that the circumstances which give rise to women's fear of persecution are often unique to women" (IRB decision TA8-05504). 45 In the absence of any discussion of how the Guidelines were applied to a specific case, this statement represents a perfunctory "speech act"; it signals compliance with the Guidelines without having to 
Table 5. IRB decisions: Domestic violence as a basis of the initial claim for principal applicants, 2008-2012

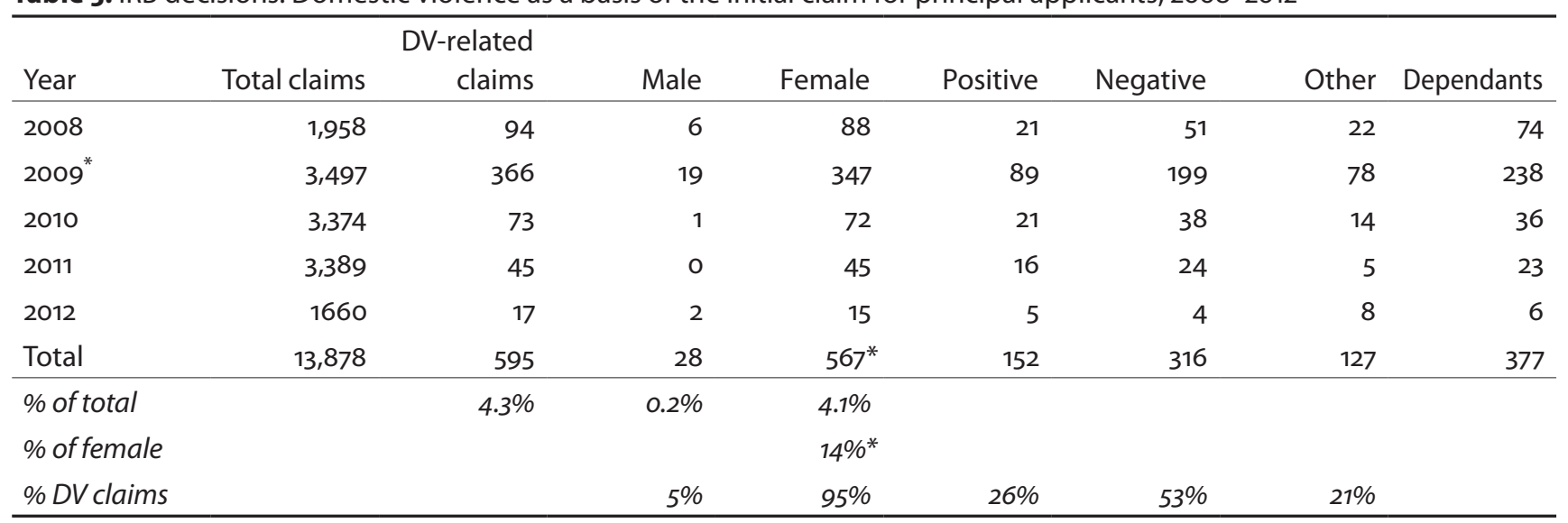

Source: Immigration and Refugee Board (IRB) data, obtained through a request for information.

* In 2009, the IRB reported that 7\% of all claims were gender-related. From 2008 to 2012, 14\% of female principal applicants indicated domestic violence as a basis of their initial claim. $95 \%$ of all claims that indicated domestic violence were submitted by female applicants, with an approval rate of $26 \%$.

demonstrate if or how the IRB adjudicators considered what circumstances are "unique to women" in their decision.

Among the decisions that provided some indication that the Gender Guidelines were discussed (18 out of 76 ), we identified three themes: (1) the influence of domestic violence on ability to demonstrate credibility and trustworthiness; (2) how the cycle of violence may include repeated attempts to leave and return to an abusive relationship; and (3) the potential for the hearing to increase women's psychological trauma. The one decision in our sample that involved a lesbian-identified woman included acknowledgement of intersections of male violence against women and homophobia.

Of the decisions in our sample, 63 were initially denied because the claimant did not seek state protection in Mexico or lacked evidence of seeking help (i.e., filing a police report, going to a women's shelter) (see table 3). Over one-third of the cases were denied for "credibility" for lack of evidence or discrepancies between the claimant's testimony and written application. More than half of the claims were denied because the board members assessed there was an "internal flight alternative."

Within the IRB member's representation of the original claim and hearing, the majority of the claimants $(83 \%)$ reported having suffered physical violence from their husband, boyfriend, or father of their child/ren. The severity of the violence varied from being slapped or hit, to having broken bones, miscarriages, and having to seek medical care. In half the cases, the claimant reported being verbally threatened, including three women who claimed that their spouse/partner threatened their lives; $16 \%$ reported suffering emotional abuse; and nearly one-third were sexually abused. Two women reported being kidnapped or averted an attempted kidnapping that was orchestrated by their spouse/partner.

More than two-thirds (70\%) stated that they reported their abuser to the police or other governmental organization and were turned away or had no response after filing a report. Of the women in this sample, five sought police protection for domestic violence while in Canada; this resulted in one claimant's spouse being deported by the Canadian Border Services Agency.

\section{Challenges to Credibility as a Gendered Performance}

According to the Gender Guidelines, the evaluation of the credibility of the claimant's evidence must consider "the social, cultural, religious and economic context in which the claimant finds herself" and whether the state is "willing or able to provide protection." In our analysis of IRB decisions, however, we noted that applicant's "credibility" was often refuted by affidavits from "legal experts."

In the following excerpt, an IRB member refers to a legal opinion on the General Law as evidence that the claimant's testimony is not credible. The claimant testified that she had made several attempts to report her husband's abuse in different jurisdictions, but that each time she met with an official she was told to report the abuse to a different office. In the decision, the IRB member referred to an affidavit submitted by a Mexican lawyer, which is one of the documents assembled by IRB staff in the National Documentation Package. This affidavit offers a legal opinion on procedures in Mexican law for responding to domestic violence complaints across jurisdictions within Mexico. On the 
basis of the lawyer's affidavit, the IRB member concluded, "This document therefore shows that it is possible to file a complaint with a state jurisdiction; the complaint would be transferred, as applicable, to another state jurisdiction ... In conclusion, the panel does not believe that the lawyers told the principal claimant that she could not lodge a complaint ... This undermines the credibility of the claimant concerning this aspect of her testimony" (IRB decision MA8-09643, 6-7; emphasis added).

The IRB member's use of an "expert" legal opinion illustrates what Mawani ${ }^{46}$ cautioned: that male authorities who are part of a system that continues to deny the severity of violence against women as a social problem are given more weight than a woman's personal testimony of her actions to seek safety and protection. The applicant's testimony was dismissed as not "possible" in the face of a legal opinion from a Mexican lawyer that was assembled a priori by IRB staff. The privileging of an "expert's" interpretation of the law's intent represents a form of authoritative male knowledge that is used to dismiss the claimant's testimony of seeking legal advice as not "possible."

Challenges to claimants' credibility also pivoted around perceptions of how victims of abuse are supposed to behave. In the following excerpt, a claimant sought protection from spousal harassment, battery, rape, verbal threats, and threats with a firearm. Throughout the testimony, the panel asked if the claimant, who lived in Mexico City, had sought help from police or an organization that supports victims of domestic violence. The claimant explained that she did not seek help because of a previous bad experience with the police (which led to her spouse retaining custody of their child) and because she no longer trusted authorities. In one instance, the claimant reported that she felt too ashamed to seek help after being raped by her spouse's friend. The panel responded: "While the panel understands that the claimant could have felt some shame in the alleged circumstances, it cannot accept these explanations; she could have at least tried to seek some protection after so many events of alleged violence" (IRB decision MA9-00629, 4).

In this decision, the IRB member presumes how victims are supposed to behave in the face of extreme cruelty. The presumption that a claimant "should at least try to seek some protection" in order for her testimony to be credible dismisses the harm caused by losing custody after reporting violence to the police or the stigma associated with marital and gang rape. Nowhere in this decision does the adjudicator reference the social and cultural attitudes that perpetuate shame for victims of sexual violence or the consequences that victims of sexual assault face when engaging the criminal justice system. ${ }^{47}$
States Are Presumed Capable of Protecting Their Citizens In the written decisions, IR B members repeatedly stated that failure of local police does not equate to the lack of state protection. Rather, the IRB adjudicators clarified that "no state can guarantee perfect protection; only adequate protection." 48 In one decision, the IR B member wrote, "Having canvassed the country conditions documents, the Panel finds that Mexico is in effective control of its territory and has in place a functioning security force to uphold the laws and constitution of the country" (IRB decision TA9-14562, 15). IRB members expected claimants to seek protection from the police or from organizations that address violence against women as a prerequisite for refugee protection. One IRB member wrote, "The simple assertion that corruption exists is insufficient to conclude that the state is incapable of protecting its citizens" (IRB decision MA9-00629, 5).

These statements demonstrate how Mexico is constructed as a "safe country of origin" prior to its appearance on the DCo list. As stated earlier, we found the national documentation package discussed implementation of the General Law in only 1 of 30 states, while failing to include recent reports on the poor coordination, police corruption, and impunity for violence across Mexico. IRB members interpret Mexican law on violence against women at face value, rather than interrogating implementation of the law.

The IRB decisions also minimize the role of the local police in upholding the General Law in Mexico. The General Law positions local police as the first level of intervention. They represent the state's capacity to protect women's rights, but also determine future state action. In cases of femicide, local police must initiate a report before a "gender alert" can be issued by the state in which the femicide took place. Thus, failure of the local police to report femicide represents a fundamental breakdown in state protection.

\section{Internal Flight Alternative}

For a case to be successful on Internal Flight Alternative grounds, the claimant "must demonstrate that a real risk to their life or a risk of cruel and unusual punishment exists throughout their country" (IRB decision TB1-08945, 6). In nearly half (45\%) of the IRB cases we reviewed, the claimant stated that she relocated to a different state within Mexico; many of them were eventually found by their abusive partner and further persecuted or threatened.

IRB members, however, rejected the majority of claims in our sample on the basis of Internal Flight Alternative grounds, concluding that cities like Mexico City and Monterrey have "a large thriving population with civic services to assist inhabitants with their social and security needs ... the Panel is of the view the claimant can easily blend into the mass of people in either city" (IRBdecision тво-03720, 
12). One board member argued that he "does not believe that, in this country with 113 million residents-more than three times Canada's population-the persecutor would have the means and the desire to search for the claimant if she decided to live in one of the IFAs [Internal Flight Alternatives]" (IRB decision MA9-10361, 11). This type of rhetoric disregards research on domestic violence that consistently shows elevated risks for victimization, if not lethal violence, when women are leaving or have left an abusive relationship. 49

Throughout the IRB decisions, we identified contradictions within board members' reasoning for denying a claim in the belief that Mexico is a functioning state capable of providing the necessary assistance to abused women. As it is noted, "Admittedly, the documentation shows that there is corruption in Mexico, that seeking protection is not always easy, and that violence against women is often a problem. However, over the years, mechanisms to assist women victims of spousal abuse have developed in Mexico, specifically in Mexico City and in Puebla in the state of Puebla, areas that have been identified as safe for the principal claimant and her children" (IRB decision MA7-09351, 7).

Despite acknowledging some limitations in the Mexican state, IRB members assert that "mechanisms" to assist women (ostensibly laws and the availability of women's shelters) render Mexico City "safe" for women and their children. Evidence of growing insecurity, including rising female homicide rates in Mexico City, are ignored. Ismail 50 raises similar concerns regarding refugee determination for Pakistani women in the United Kingdom, where refugee claims are often denied on the presumption that women have options for internal relocation, despite the dangerous circumstances that prevent women from relocating within their own country. In this sense, Canadian IRB members collude with the Mexican government to minimize the state of violence and insecurity that has been documented by local and international human rights organizations. The Internal Flight Alternative requirement deflects Canada's humanitarian responsibilities and upholds Mexico's incapacity to address systematic violence against women as "adequate."

\section{Conclusion}

Our research illustrates how Canadian refugee adjudicators construct Mexico as a "safe country of origin" for women seeking protection from domestic violence. Throughout the written decisions that we reviewed, IRB adjudicators refer to Mexico as a "democratic nation"; a nation that is "in control of its territory"; with "mechanisms" (i.e., laws and women's shelters) to offer assistance to victims of domestic violence. Within Mexico, the passage of anti-violence-against-women laws are important steps towards acknowledging women's rights as human rights. Reports from non-governmental organizations and international watchdogs like Amnesty International, however, have documented shortcomings in how the law is implemented. Legal instruments to protect women fall dramatically short when considering the high rates of impunity in Mexico for violent crimes, including rape, domestic violence, and femicide. The IRB decisions, however, downplay the context of increased levels of violence and associated impunity. The representation of Mexico as "safe" has direct implications for refugee claimants who, as a result, face a higher burden of proof that the state failed to protect them.

Considering Macklin's ${ }^{51}$ earlier attention to the dichotomy of refugee-producing vs. refugee-accepting countries, we illustrate the consequences of political discourse that frames Mexico as capable of offering protection for domestic violence. The "higher burden" of proof for Mexican refugee claimants reproduces victim-blaming attitudes that minimize the structural barriers and institutional misogyny that deter women from seeking state protection from domestic violence in Mexico-a phenomenon that similarly contributes to low rates of reporting domestic violence or sexual assault crimes in Canada. We also noted that while gender has become incorporated or "mainstreamed" in refugee determination, the majority of published IRB decisions in our sample paid little attention to the context of impunity for violent crimes against women in Mexico. When IRB members did reference the legal context in Mexico, they regularly privileged the authoritative knowledge of legal documents, rather than evidence of the law in practice. IRB members' representation of Mexico as a functioning democracy in control of its territory thus operates as a rhetorical rather than empirically supported assertion. The poor implementation of laws that criminalize violence against women and limited support services reinforces a distinction between juridical rights (what is stated in law) and "notions of protection." 52 As such, we caution the appearance of antiviolence-against-women laws as an adequate benchmark for determining protection from gender-based violence.

Although it is the primary source of refugee protection for Mexican asylum-seekers worldwide, Canada's restrictions on humanitarian migration (e.g., the Safe Third Country Agreement, visa restrictions, the list of Designated Countries of Origin) significantly reduce the legal options for Mexicans to find refuge. Furthermore, Canadian IRB members' emphasis on Mexico's stature as a “democratic nation" reinforces global hierarchies of what constitutes a "well-founded fear of violence." By placing Mexico on a "safe" country list, Canada in effect affirms that everyday violence against women is unworthy of international intervention. This indirectly reinforces Canada's tolerance for high rates 
of domestic violence and sexual assault within its own borders, especially for indigenous women, trans people, and women with disabilities, where only a fraction of cases are reported to law enforcement or lead to criminal conviction. Because the prevalence of violence against women as a "legitimate" or normalized part of everyday life persists in many regions of the world, refugee determination under the UN convention remains an unfulfilled space to advocate for safety from domestic violence as a human right.

\section{Notes}

1 Efrat Arbel, "Culture of Rights Protection in Canadian Refugee Law: Examining the Domestic Violence Cases," McGill Law Journal 58 (2013): 729-71.

2 Efrat Arbel and Alletta Brenner, Bordering on Failure: Canada-U.S. Border Policy and the Politics of Refugee Exclusion (Boston, MA: Harvard Immigration and Refugee Law Clinical Program, 2013); Audrey Macklin, "Refugee Women and the Imperative of Categories," Human Rights Quarterly 17, no. 2 (1995): 213-77; and Sherene H. Razack, "Domestic Violence as Gender Persecution: Policing the Borders of Nation, Race and Gender," Canadian Journal of Women \& Law 8 (1995): 46-88.

3 Ibid.

4 Rupaleem Bhuyan, Bethany Osborne, and Janet Flor Juanico Cruz, “'Once you arrive, se te sala todo' (everything is salted): Latina Migrants' Struggle for 'Dignity and a Right to Life' in Canada," Journal of Immigrant and Refugee Studies (2016), http://dx.doi.org/10.1080/15562948 .2016.1147630.

5 UNHCR, 2015 Likely to Break Records for Forced Displacement: Study (Geneva: United Nations High Commissioner for Refugees, 2015). Although El Salvador, Guatemala, and Honduras are considered "postwar," migration is constant as the result of ongoing violence, natural disasters, and exacerbated poverty. Civil society and non-governmental agencies (e.g., Washington Office on Latin America, Amnesty, Human Rights Watch) have documented the protection-worthy status of many Central American migrants who enter Mexico and the United States, yet there is limited protection through the U.N. Convention for Refugees. Further, implementation of the U.S.-Canada Safe Third Country Agreement and U.S.-supported Plan Programa Sur in Mexico has led to increased detention, extortion, and risk for violence for migrants from this region.

6 Mexican Commission for the Defense and Promotion of Human Rights, Femicide and Impunity in Mexico: A Context of Structural and Generalized Violence (New York: Committee on the Elimination of All Forms of Discrimination against Women, 2012).

7 Sean Rehaag, "2012 Refugee Claim Data and IRB Member Recognition Rates," Canadian Council for Refugees, 2013, http://ccrweb.ca/en/2012-refugee-claim-data. In the
Canadian system, Immigration and Refugee Board members are politically appointed, thus the selection of IRB members reflects their political connections more than their level of knowledge in immigration law.

8 R. Castro and F. Riquer, "Claroscuros En El Conocimiento Sobre La Violencia Contra Las Mujeres," in Retratos De La Violencia Contra Las Mujeres En México. Análisis De Resultados De La Encuesta Nacional Sobre La Dinámica De Las Relaciones En Los Hogares, ed. I. Casique and R. Castro, 9-39 (Mexico: Instituto Nacional de las Mujeres, 2012). See also Melissa Wright, "Necropolitics, Narcopolitics, and Femicide: Gendered Violence on the Mexico-Us Border," Signs 36, no. 3 (2011): 707-31, for her analysis of the politics of how violence in Mexico is portrayed by different political interests. NGOs and human rights groups call attention to "escalating forms of violence," while the Mexican government declares that it is meeting international conventions for the eradication of violence against women.

9 Instituto Nacional de Estadística y Geografía, Encuesta Nacional sobre la Dinámica de las Relaciones en los Hogares (ENDIREH) (Aguascalientes, Mexico: Instituto Nacional de Estadística y Geografía, 2011).

10 Castro and Riquer, "Claroscuros En El Conocimiento."

11 United States of Mexico. Article 1, The General Law on Women's Access to a Life Free of Violence, 2007.

12 Ibid.

13 UNHCR, Population Statistics (Geneva: United Nations High Commissioner for Refugees, 2015).

14 Immigration Refugees and Citizenship Canada, Facts and Figures 2014 (Ottawa: Government of Canada, 2015).

15 Anna J. Calbot, "Problems Faced by Mexican Asylumseekers in the United States," Journal on Migration and Human Security 2, no. 4 (2014): 361-77.

16 Audrey Macklin and Kenneth M. Waldman, “Ottawa's Bogus Refugee Bill.” Toronto Star, 16 February 2012; Paloma E. Villegas, "Assembling a Visa Requirement against the Mexican 'Wave': Migrant Illegalization, Policy and Affective 'Crises' in Canada,' Ethnic and Racial Studies 36, no. 12 (2013): 2200-19; Liette Gilbert, "The Discursive Production of a Mexican Refugee Crisis in Canadian Media and Policy," Journal of Ethnic and Migration Studies 39, no. 5 (2013): 827-43. Canada also introduced a visa requirement for the Czech Republic, to block Roma migrants. Visa restrictions were lifted for the Czech Republic in 2013 in response to pressure from the European Union and for Mexico in 2016 under the Liberal government.

17 In July 2015, the Federal Court of Canada ruled that denying refugee claimants the right to appeal their decision violates the Canadian Charter of Rights and Freedoms. The Prime Minister Justin Trudeau promised to amend the rule, soon after assuming power in the fall of 2015, but has yet to do so.

18 Lorne Waldman and Audrey Macklin, "Why We Can't Turn Away the Tamil Ships," Globe and Mail, 17 August 2010. Waldman and Macklin call attention to the emotive 
reaction Canadians display when "boats" carrying refugees land on Canadian shores-from denying the entry of Sikhs on the Komagata Maru in 1914; Jewish refugees fleeing the Holocaust; and most recently criminalizing Tamil passengers of the Mv Sun Sea in 2010 after their ship arrived from Sri Lanka.

19 Marie Lacroix, "Canadian Refugee Policy and the Social Construction of the Refugee Claimant Subjectivity: Understanding Refugeeness," Journal of Refugee Studies 17, no. 2 (2004): 147-66.

20 Arbel and Brenner, Bordering on Failure.

21 Ibid.

22 Steven Chase, "New Fast-Track Rules See Big Drop in Refugee Asylum Claims," Globe and Mail, 21 February 2013.

23 United Nations High Commissioner for Refugees, Population Statistics.

24 Nurjehan Mawani, "The Factual and Legal Legitimacy of Addressing Gender Issues," Refuge 13, no. 4 (1993): 7-10.

25 Macklin, "Refugee Women and the Imperative of Categories."

26 Ibid., 36-7.

27 Sherene H. Razack, "Domestic Violence as Gender Persecution: Policing the Borders of Nation, Race and Gender," Canadian Journal of Women \& Law 8 (1995): 46-88.

28 Here Razack calls attention to Western hegemony and the role of Western nations, like Canada, in perpetuating global inequities. She specifically critiques the role of racialized knowledge production, or racialized power in constructing refugee discourse. Sherene H. Razack, Looking White People in the Eye: Gender, Race, and Culture in Courtrooms and Classrooms (Toronto: University of Toronto Press, 1998), 48-50.

29 Ibid., 8o.

30 Arbel, "Culture of Rights Protection in Canadian Refugee Law."

31 Ibid., 756-7.

32 Efrat Arbel, Catherine Dauvergne, and Jenni Millbank, Gender in Refugee Law: From the Margins to the Centre, Routledge Research in Asylum, Migration and Refugee Law (London: Routledge, Taylor \& Francis Group, 2014).

33 See Sean Rehaag, "Troubling Patterns in Canadian Refugee Adjudication," Ottawa Law Review 39, no. 2 (2008): $335-65$.

34 Sean Rehaag, "Do Women Refugee Judges Really Make a Difference? An Empirical Analysis of Gender and Outcomes in Canadian Refugee Determinations," Canadian Journal of Women and the Law 23, no. 2 (2011): 627-6o.

35 N. L. Fairclough, and R. Wodak, "Critical Discourse Analysis," in Discourse Studies: A Multidisciplinary Introduction, ed. T. A. van Dijk, 258-84 (London: Sage, 1997).

36 Michel Foucault, Power/Knowledge: Selected Interviews and Other Writings, 1972-1977, trans. Colin Gordon et al., ed. Colin Gordon (New York: Pantheon, 1980); Foucault,
"The Subject and Power," in Michel Foucault: Beyond Structuralism and Hermeneutics, ed. H. L. Dreyfus and P. Rainbow, 208-28 (Chicago: University of Chicago Press, 1989); Michelle M. Lazar, "Feminist Critical Discourse Analysis: Articulating a Feminist Discourse Praxis," Critical Discourse Studies 4, no. 2 (2007): 141-64.

37 J. P. Gee, An Introduction to Discourse Analysis: Theory and Method (New York: Routledge, 1999); Chela Sandoval, Methodology of the Oppressed (Minneapolis: University of Minnesota Press, 2000).

38 Canadian Legal Information Institute, https://www.canlii. org/en/.

39 Rehaag, "Troubling Patterns in Canadian Refugee Adjudication”; Rehaag, "2012 Refugee Claim Data and IRB Member Recognition Rates."

40 Castro and Riquer, "Claroscuros En El Conocimiento"; Sonia M. Frias, Gender, the State and Patriarchy: Partner Violence in Mexico (Saarbrucken, Germany: vDM Verlag 2009); Mercedes Olivera, "Violencia Femicida: Violence against Women and Mexico's Structural Crisis," American Perspectives 22, no. 2 (2006): 104-14.

41 Immigration Refugee Board of Canada, "Responses to Information Requests," 3 June 2008, para. 10, http://irb-cisr .gc.ca/Eng/ResRec/RirRdi/Pages/index.aspx?doc $=451949$.

42 Padgett Humberto and Eduardo Loza Vasquez, Las Muertas Del Estado: Feminicidio Durante La Administración Mexiquense De Enrique Peña Nieto (Mexico: Penguin Random House Grupo Editorial México, 2014); Olivera, "Violencia Femicida."

43 Cedar Attanasio, "Femicide in Mexico: Conviction in Juarez Murder Case Reached by Three Female Judges," Latin Times, 10 July 2015.

44 Arbel, "Culture of Rights Protection in Canadian Refugee Law."

45 Immigration and Refugee Board decisions are available from the Canadian Legal Information Institute, http:// www.canlii.org/en.

46 Mawani, "Factual and Legal Legitimacy of Addressing Gender Issues."

47 K. G. Weiss, "Too Ashamed to Report: Deconstructing the Shame of Sexual Victimization," Feminist Criminology 5, no. 3 (2010): 286-310.

48 "Adequate protection" is based on the presumption that the country of origin is capable of providing protection to the individual, unless the country is in a position of complete breakdown or the claimant provides sufficient evidence that the state failed to protect them. Canada (Attorney General) v Ward, [1993] 2 scR 689.

49 Zoran Miladinovic and Leah Mulligan, "Homicide in Canada, 2014," Juristat 35, no. 1 (2015): 1-42; Douglas A. Brownridge, "Violence against Women Post-Separation," Aggression and Violent Behavior 11, no. 5 (2006): 514-30; World Health Organization, Responding to Intimate Partner Violence and Sexual Violence against Women: wHо 
Clinical and Policy Guidelines (Geneva: World Health Organization, 2013); Arbel, "Culture of Rights Protection in Canadian Refugee Law."

50 Sajida Ismail, "Safe to Return? A Case Study of Domestic Violence, Pakistani Women and the uk Asylum System," in Gender and Migration: Feminist Interventions, ed. Ingrid Palmary, Erica Burman, Khatidja Chantler, and Peace Kiguwa, 86-103 (London: Zed Books).

51 Macklin, "Refugee Women and the Imperative of Categories."

52 Lobat Sadrehashemi, "Gender Persecution and Refugee Law Reform in Canada," (2011), http://www.bwss.org/ wp-content/uploads/2011/o4/GENDER-PERSECUTION-andREFUGEE-LAW-REFORM-IN-CANADA_2.pdf.
Rupaleem Bhuyan is an associate professor in social work at the University of Toronto and lead researcher with the Migrant Mothers Project. The author may be contacted at r.bhuyan@utoronto.ca.

Adriana Vargas received a $B A$ (Hons.) in criminology from the University of Toronto and is a research coordinator with the Migrant Mothers Project. The author may be contacted at adriana.vargas@mail.utoronto.ca.

Margarita Pintin-Perez is a PhD candidate in the department of Society and Culture at El Colegio de la Frontera Sur. The author may be contacted at mjpintin@ecosur.edu.mx. 